\title{
Unsettling the Binarisms of Dominant Discourse in Hanay Geiogamah's Plays Body Indian and Foghorn
}

\section{Danica Čerče}

\section{Abstract}

This essay deals with two plays by the contemporary Native American author Hanay Geiogamah, Body Indian and Foghorn. Based on the premise that literature plays an important role in disrupting the exercise of power and written against the backdrop of critical whiteness studies, it investigates how the playwright intervenes in the assumptions about whiteness as a static privilege-granting category and system of dominance.

Keywords: Native American playwriting, Hanay Geiogamah, Body Indian, Foghorn, destabilising whiteness 
There is no shortage of evidence that writing has played an important role in both establishing whites as authoritative in relation to non-white subjects and in the processes of decolonisation. The latter have involved "a radical dismantling of European codes and a postcolonial subversion and appropriation of the dominant European discourses," claims Helen Tiffin (95). Interrogating these discourses and the social context in which healthy social interactions between white and indigenous people are impeded because of the presupposed foundation of apparently undislocatable binary oppositions upon which the logic of coloniality stands, literary engagement of indigenous population can be seen as an integral part of an organised protest against colonialist authority. In a Canadian context, Armand Garnet Ruffo (1997) argues that Native literature parallels and mirrors the political resurgence of indigenous people. In a US context, several theorists and artists have made similar claims, seeing literary activism as a way of contesting prevailing power structures. For example, an activist and playwright Monique Mojica has stated that Native American artists offer "an alternative view, the possibility of another interpretation of 'historical facts' and the validation of Native American experiences and images" (1).

Constituting an intercultural encounter for the white reader and intervening in the institutional and historical processes that have enabled and maintained the dominant position of those identified as white on the one hand, and the concomitant political, economic, and cultural subordination of indigenous population on the other, Native American literature articulates discourses of "conscious antagonists," as Edward Said refers to those who, "compelled by the system to play subordinate roles within it," react by disrupting it (335). Performing this function, it has earned the label "literature with a purpose," which - according to the Cherokee scholar Jace Weaver - can be applied to all postcolonial literatures (44). Here it is relevant to mention that, despite sharing affinities with other postcolonial literatures in that it has also "emerged out of the experience of colonization" and asserted itself by "foregrounding the tension with the imperial power" and by "emphasising the differences from the assumptions of the imperial Centre" (Ashcroft, Griffiths, and Tiffin 2), the status of Native American literature remains unclear in the postcolonial scholarship. ${ }^{1}$

In this study, I focus on the plays Body Indian and Foghorn by Hanay Geiogamah, a Kiowa-Delaware political activist and one of the most prominent contemporary Native American playwrights. My reading is not concerned with the 'literariness' as a principal object of study and appreciation; rather, it is framed by

1 Several non-Native scholars have expressed scepticism towards the applicability of the term 'postcolonial' to both Native Americans' life and literature (Krupat 73). In Arnold Krupat's view, this is for the simple reason that "there is not yet a 'post-' to the colonial status of Native Americans (Ibid.). 
an interest in how the two plays function as "a form of public good" (Gonzales and Agostini xvi) or what David Carter and Kay Ferres define as "the public life of literature" (140). Drawing on some of the issues taken up by critical whiteness theory, the study aims to show how the playwright intervenes in the controlling discourses of colonialism that have retained the American indigenous population in the web of hegemonic power. I argue that one of the main textual devices that Geiogamah employs to do what he sees as "the challenging task of the new Native American theatre" (Geiogamah 2000,163) is humour.

For Native Americans, the essential theatrical impulse has a long history. Performance was integrated into many aspects of Native cultural life long before the invasion of Europeans. Ceremonies performed for well-being and protection and to celebrate or mourn life-cycles included the theatrical elements of storytelling, song, dance and costume to create the emotional and spiritual impact. Today, many Native American playwrights draw upon traditional tribal performance practices and characters to inform their work. First plays by a Native American were published between the late 1920s and early 1950s by the Cherokee playwright Lynn Riggs. ${ }^{2}$ Dealing with the various forms of extreme racism inflicted upon the Cherokee during the transformation of Indian Territory to Oklahoma's statehood, Riggs's plays foreshadow the concerns explored by Native American playwrights a few decades later, such as representation, authenticity, and cultural and political empowerment of indigenous population.

The contemporary era of Native American playwriting is connected with the rise of Native Americans' activism in the late 1960s and the 1970s, manifested in the form of various movements demanding increased civil rights, tribal sovereignty, and self-determination. Among them, the American Indian Movement (AIM) rapidly became a militant force for indigenous Americans' rights throughout the country (Darby 156). During that period of political unrest and cultural rebirth, Geiogamah recognized the political potential of theatrical performance. He claimed that the role of Native American artists was to "establish a strong identity base in their work to help confront and clarify the endless confusions resulting from non-Indians' beliefs and misperceptions of Indian life, [...] to help untangle the mass of confusions that stereotyping, assimilation, and acculturation have created in the minds of Indians themselves" (Geiogamah 2000,163).

Geiogamah's plays are included in two anthologies of Native American drama: Seventh Generation: An Anthology of Native American Plays (1999) and Stories of Our Way: An Anthology of American Indian Plays (1999). The two plays discussed

2 Riggs is the author of several notable Broadway plays, including the 1931 Green Grows the Lilacs, upon which the composer Richard Rodgers and the librettist Oscar Hammerstein based their famous musical Oklahoma!. 
in this article, Body Indian and Foghorn, first staged in 1972 and 1973, respectively, were published in 1980, together with the play 49 and under the title New Native American Drama: Three Plays by Hanay Geiogamah. Generally regarded as Geiogamah's major plays, they were first performed by the Native American Theatre Ensemble, founded by Geiogamah himself. As Jaye Darby has noted, they display a "distinctive Native American aesthetic of threatre," fusing the inheritance of tribal cultures in Native American communities with current issues, while recognizing western theatrical traditions (157). In particular, they show the influence of Bertolt Brecht, visible in Geiogamah's non-traditional theatrical techniques in portraying the contradictions, struggles and conflicts of contemporary social life in the United States.

\section{GEIOGAMAH'S THEATRICAL RHETHORIC}

Some critics compare Geiogamah's theatrical rhethoric to the radical black theatre of the 1960s. Among the opposing voices, Jeffrey Huntsman argues that Geiogamah is more interested in survival and self-knowledge of his people than in "reproach and confrontation," urging them "to note their condition, whether it arises from external prejudice or from their own mistreatment of one other" (xi). Huntsman justifies his opinin by pointing to Geiogamah's statement that the most important role of Native American authors is to communicate with their own people (Geiogamah 2000,163). Weaver positions Geiogamah's work within what he calls the "communitist tradition" in the Native American playwriting, that is, combining community and activism (43). In communities that have been rendered dysfunctional by the effects of settler colonialism, to promote communitist values means "to participate in the healing of the grief and sense of exile felt by Native communities and the pained individuals in them," claims Weaver. In his wiew, Native American authors prepare the ground for the recovery and even recreation of Native American identity and culture, or - as the scholar contends in the title of one of his studies - they write "[ $t]$ hat the people might live" (43-44).

Indeed, Geiogamah sees the stage as a means of Native Americans' self-realization and of presenting their cultural authenticity. To perform this educative function, Geiogamah places the realities of contemporary Native American life in the context of a long history of his peoples' oppression and struggle. It is probably safe to claim that the most consistent theme in his plays is "the past bearing down upon the present," as Katharine Brisbane observes for contemporary dramatic activity in Australia (xv). Although this theme has various realizations in Geiogamah's plays, taken as a whole, his dramatic output constitutes a reinterpretation of American social history from a Native American point of view, inviting the 
audience to reconcider the relationships formed on the basis of dominating discourses. Understanding the need for Native Americans to free themselves from a "massive psycho-existential complex," as Frantz Fanon $(1986,216)$ calls the psychological internalization of colonizer's values about the colonized, marked by a sense of inferiority, Geiogamah challenges the reproduction of discriminatory identities and empowers his people. To do this, he employs several theatrical devices, such as language, humour, structure, and dialogue.

Beginning with the language, it is generally regarded as the most important vehicle through which the colonizers effected the "spiritual subjugation" (Ngugi 287). Embracing the view about language as "inseparable from ourselves as a community of human beings with a specific form and character, a specific history and relationship to the world" and thus "crucially related to the need for a secure cultural identity and to the achievement of self-esteem and self-determination," expressed by the Kenyan writer and theorist Ngugi wa Thiong'o (290), ${ }^{3}$ several postcolonial theorists claim that decolonization can be achieved only with the full independence of culture, language, and political organization. Several others tend to concur with Bill Ashcroft, Gareth Griffiths and Helen Tiffin, who see "cultural syncreticity" as a valuable and unavoidable feature of all formerly colonized societies and argue that the colonizer's language is capable of accounting for postcolonial experience if it develops an appropriate usage (30). In their view, the language of the centre needs to be re-placed by a discourse which is "fully adapted to the colonized place" (Ashcroft, Griffiths and Tiffin 37). Like a number of other Indigenous authors, Geiogamah has liberated himself from the linguistic and cultural chains, and reformed the colonizer's language to become an expression of his peoples' experience. In the "Author's Note" to Body Indian, for example, he writes several suggestions for the actors in order to imitate the real speech of the protagonists and establish an authentic-sounding Native American dialect, such as dropping the final 'g' (goin'), jamming words together (lotta), adding a grammatically superfluous final 's' (mens), leaving a hiatus between a final and an initial vowel (a old one), and others (17). Clearly, Geiogamah's appropriation of English to the local needs and requirements demonstrates his refusal to accede to the kind of world and reality the use of the imperial language implies.

Referring to black American authors, Lorraine Hansberry observes that, since they must also write for the market that is the object of their protest, it is important

3 Ngugi wa Thiong'o writes exclusively in the Gikuyu language, one of the Kenyan languages. In Ngugi's view, writing in their peoples' mother tongues, associated with backwardness, underdevelopment and other negative qualities, will contribute to the restoration of the harmony between all aspects of language. He also claims that this alone will not cause the renaissance of Kenyan and African cultures unless that literature carries "the content of their peoples' anti-imperialist struggles to liberate their productive forces from foreign control” $(2003,290)$. 
for them to write so that the audience is constrained to applaud the very protest directed towards it (Davis iii). This is also how Geiogamah writes. "Theatre, to me, is probably the most peaceful form of resistance against a colonial government. There's no bloodshed. That's the reason I do theatre, to bring about change. To bring about the healing process. But also, to enrich human beings," Geiogamah reveals in his interview with Charlotte Stoudt (Stoudt 60). Influenced by Brecht's theatrical innovations and in accord with the Native Americans' wisdom that "in laughter is truth" (Huntsman xvi-xvii), Geiogamah relies on humour and parody as important textual vehicles not only for defamiliarizing whiteness, but also for restoring dignity and social hope among his people. ${ }^{4}$

\section{BODY INDIAN}

Set in present-day western Oklahoma, the play Body Indian addresses the personal and social costs of alcohol abuse among Native Americans. It depicts a two-day drinking gathering of Bobby Lee and his Kiowa relatives and friends. The play begins with Bobby struggling on crutches into his one-room apartment, where the party is held. Handicapped by the loss of a leg in a train accident during one of his previous drinking sprees, he is carrying groceries and wine he bought with the money obtained from leasing his allotment of reservation land. ${ }^{5}$ As Bobby reveals to his companions, he intends to use the rest of his lease money to enter a sixweek alcohol rehabilitation programme. However, by the end of the play, in the process of the progressive erosion of kinship ties delineated in the opening scene, he is either asked for money or had it all stolen. Finally, the drunks take Bobby's artificial leg and pawn it to buy more wine.

Citing Geiogamah's comment that Body Indian "is a play of the past and the present, but hopefully not of the future," depicting "how Indians abuse and mistreat one another in a dangerously crippling way," Darby describes the play as staging a "poignant appeal" for the restoration of traditional tribal values of respect and responsibility, disrupted by the forced displacement (160-161). The play's intense and shocking realism also suggests other interpretive possibilities. Despite presenting a situation of "near hopelessness," the play's theme is survival, claims

4 The Australian sociologist Ghassan Hage has observed that dignity and social hope, access to which seems to be exclusively a white entitlement, allows people to imagine a future for themselves, whereas the withholding of it from minority constituencies in effect denies them a participatory role in imagining the future of the nation (22).

5 Because of the U.S. federal allotment policies in Indian Territory in the late 1880s and early 1900s, each Native household received 160 acres of land as replacement for millions of acres taken from the tribes. Under the control of the Bureau of Indian Affairs, many Native Americans leased out this land (Darby 160-161). 
Jack Marken (376). Seeing the main character's suffering as "redemptive," Huntsman also describes it as "a play of optimism and triumph" (xvii). Norma Wilson, on the other hand, views the play as "a bleak dramatization of the effects of alcoholism" (85). There is truth on both sides: the play brings a social problem into the light of community attention and underscores that Native Americans can survive the most hopeless of situations on condition that they regain their lost sense of community. The audience is reminded of this imperative with the sound of an approaching train mixed with the sound of drums and dance rattles at the end of each scene.

The recurring sound of a train can also be viewed as a reminder to European Americans of their brutal displacement of Native Americans from their homelands and of their systemic racialized oppression. Although, in Geiogamah's words, his plays are primarily intended for Native Americans, Body Indian also addresses a white audience and challenges their assumptions about the superiority and entitlement of their race. The third scene, in particular, abounds in critique of a discourse that relegates and confines the non-Europeans to a secondary status. Geiogamah's exposure of the harsh reality of unemployment and povery, materialized in bad housing conditions, poor diet, limited educational possibilities and dependence on government support, is imbued with sadness and sometimes even despair as in the following dialogue:

Alice: I can't even get on state welfare. They say my husband is able to work. He's able, but there's no work.

Betty: All those white people think Indians have it good because they think the government takes care of us. They don't even know. It's rougher than they know. I'd like to trade my house for a white lady's house on Mission Street. I'd like for a white lady to have my roaches. You see them at the store, and they look at you like your purse is full of government checks. I wish my purse could be full of government checks.

Alice: I wish I had a check from anywhere. (Geiogamah 1980, 23-24)

Clearly, Geiogamah uses the stage to affirm his people's cultural substance in the face of ongoing cultural, economic and political subjugation, and to expose the forces that still prevent liberation, whether these be the oppressions of the whites or the illusions of white superiority ingrained within the oppressed themselves. In these circumstances, Geiogamah's characters seek refuge in excessive drinking. Obviously aware of the controversial nature of the play's content, Geiogamah writes in the "Author's Note" that the acting should nowhere give the false impresion of the play being primarily a study of the problem of alcoholism among $\mathrm{Na}$ tive Americans (8). Given that performance may function as "an act of transfer," 
conveying social knowledge, values and memories from one group to another and from one generation to the next (Taylor 2), Geiogamah is counting upon the repertoire and embodiment to challenge white audience members' stereotyped expectations of contemporary Native American life, notes Julie Pearson (122). According to Pearson, the play exposes "the colonialist discourse of alcoholism," that is, a historical awareness of the political causes of alcoholism, systematically utilized by the colonizer to disempower the colonized and reinforce its own power (Ibid.). Another pernicious effect of this discourse is its internalization by Native Americans demonstrated in the tendency to express their rebellion against what are perceived as white social norms with alcohol addiction (Ibid.). ${ }^{6}$ Showing the host of the party broke and alone at the end, the play allows no doubt that this kind of resistance is destructive - alcohol addiction causes new problems, rather than solving any.

Vine Deloria Jr. has observed that "Indians can find a humorous side to nearly every problem [...]. The more desperate the problem, the more humour is directed to describe it" (635-636). Throughout the play, regarded by Geiogamah as "his toughest" (Pearson 122), humour tempers the truth. For example, when women complain about their chronic lack of money, Bobby says:

Every Indian needs to have a government check for twenty-five thousand. They could give you womens fifty thousand. Then you could buy all your kids shoes, clothes, bicycles, pay rent, pay fines, buy shawls and earrings, and put the money you have left in the bank to live on. That's the only way you'd ever have the money you need. (Geiogamah 1980, 22)

Although the play provokes laughter, it critically portrays the underbelly of a country that has supported what George Lipsitz calls the "racialized nature of social policy" (5). Echoing with a call for justice, inclusion and equality, Body Indian passionately engages both Native American and white spectators. Whereas some of the former identify with the irony of the characters' lives and the discrepancy between their desires and behaviour, and react to the play with strong laughter, others denounce it as "a disservice to the Indian community," claiming that it merely perpetuates stereotypes and adds to distorted representations of Native Americans (Pearson 124). For white spectators, Body Indian's "act of transfer" is a better understanding of contemporary Native American political and socio-economic condition. Faced with the effects of the American government's failure and the larger American society's complicity in addressing the Native Americans'

6 Eduardo and Bonnie Duran have observed that, during the 1970s, the perception of alcoholism as a mode of rebellion was so strong among Native Americans that one popular prevention poster bore the slogan, “Drinking won't make you more Indian” $(1995,28)$. 
poverty with all its attendant ills, many of them are imbued with strong feelings of moral indignation and forced to rethink the concept of whiteness as manifested in their past and present attitudes to Native Americans. Reinstating knowledge, dignity and hope for Native communities, Body Indian can probably be seen to contribute to the "undo[ing of] the racist structure of the colonial matrix of power" and a "genealogy of de-colonial thought" (Mignolo 391). A similar intervention in the country's racist structure of power ${ }^{7}$ and colonialist representations is also performed in Geiogamah's play Foghorn.

\section{FOGHORN}

For decades, Native American characters, like other minority characters in American literature and entertainment media, were highly stereotyped and never fully developed or given any agency. This was particularly true in film, given that until very recently, creative control was almost exclusively in the hands of white producers (Haugo 190-191). However, the distorted images constructed by white Americans during the expansion and domination of the "Frontier" are not yet a thing of the past. On the contrary, they are still present throughout American culture, claims Jodi Van Der Horn-Gibson, among others, pointing to the figure of the Native American in the twenty-first century theatre, film and story adaptations of Peter Pan (126). Various popular images from the past, including those of the 'noble savage,' 'bloodthirsty redskin,' or 'drunken Indian,' disseminated through Karl May's "colonial fairy tales" (Weaver 18), for example, continue to reinforce the mainstream understanding of European identity as superior in relation to all 'others.'With dominant cultures typically acting in an ethnocentric way, it is thus important for Native authors to mobilize strategies of indictment, argumentation, perasuasion and advocacy in the service of a central agenda, that is, the destabilization of the means by which Europe imposed and maintained its dominant discourse (Tiffin 95).

Technically a modern multimedia satire, with elements such as lights, graphics and electronic music juxtaposed with traditional elements of the tribal past, Foghorn is a penetrating confrontation with enduring racist stereotypes and cultural hegemony. Premiered in Berlin in 1973, when conflicts between the United States government and the indigenous communities over treaty disputes and land rights issues were particularly intense, the play includes two crucial events from that period, the Native Americans' occupation of Alcatraz Island from 1969 to 1971

7 In his 2000 article "Race and the Social Contract Tradition," Charles Mills argues that, in the United States, "race is not anomalous to the American democracy but fundamental to it" (450). Similar views are also expressed in his 2015 article, "Breaking the Racial Contract." 
and the 1973 Wounded Knee incident. ${ }^{8}$ The opening scene, presenting Native Americans on a forced journey, alludes to the march of the nineteenth-century victims of the Trail of Tears. ${ }^{9}$

Despite its setting in tragic episodes from the Native Americans' struggles with the whites, beginning with the landing of Columbus in 1492, Foghorn proceeds "by playful mockery rather than bitter denunciation," as Geiogamah explains in the "Author's Note" $(1980,49)$. The author further suggests that "the production should aim at a light, almost frivolous effect," claiming that the serious topic of the play will emerge more effectively if the "heavy hand is avoided" (Ibid.). In Huntsman's words, the play appears as a set of loosely connected mocking remarks, much like a minstrel show (xviii). However, funny in isolation, the scenes are tellingly connected, expressing protest against the Native peoples' assigned position of inferiority and the strategies of homogenization and assimilation, which had served the American melting-pot ideology since the late $19^{\text {th }}$ century. It has to be remembered that, by the end of the 1960s, the dominant ideology of assimilation had created specific institutional practices, described by David Theo Goldberg as: "[ $t]$ hose who could not be assimilated were wiped away, representationally, symbolically and, in many instances, physically" (5-6). Scene 4, for example, with a school teacher's hysterical praise of white civilization and the English language, is well illustrative of what Weaver describes as: "The night of the sword and the bullet was followed by the morning of the chalk and blackboard. The physical violence of the battlefield was followed by the psychological violence of the classroom" (13):

You Indians are going to be educated. [...] You are going to learn how to be Christians, how to worship God and live a clean, wholesome, decent life. You are going to learn how to be civilized people, civilized Indians. [...] You are going to forget all your Indian ways, all of them. You can start erasing them from your minds right now, right here, right this instant. No more of your disgusting sign language. No more of your savage tongue. No more greasy, lousy hair. No more blankets. You are going to learn English language. [...]

8 In accordance with the Indian Reorganization Act of 1934 and the Treaty of Fort Laramie (1868) that all abandoned or out-of-use federal land was to be returned to Native people, a group of American Indian Movement (AIM) supporters occupied Alcatraz Island after Alcatraz federal prison was closed in spring 1963. The occupation lasted for nineteen months before it was forcibly ended by U.S. government in 1969.

The 1973 siege of the town Wounded Knee (the place of 1890 massacre) in South Dakota by members of the Sioux Nation led by supporters of AIM lasted 71 days. This Native Americans' response to the U. S. government's failure to honour the treaties, triggered by a brutal murder, is regarded as one of the biggest successes of AIM, drawing attention to Native Americans' unsafe living conditions and mistreatment by both federal and local agencies.

9 The term refers to a series of forced relocations following the Indian Removal Act of 1830. 
The English language. The most beautiful language in all the world. The language that has brought hope and civilization to people everywhere. The one true language. OUR language! [...] I am going to teach you your first word of English. Listen carefully, for it is the word, the one word, you must know first to become civilized. [...] The American way begins with Hell-O." (Geiogamah 1980, 61)

The above passage, which describes the cruelty of assimilation strategies used by the dominant culture, contrasts ironically with that from the 1969 Alcatraz Proclamation in scene 2 :

We will further guide the majority inhabitants in the proper way of living. We will offer them our religion, our education, our way of life-in order to help them achieve our level of civilization and thus raise them and all white brothers from their savage and unhappy state. (Geiogamah 1980, 55-56)

Similarly, the United States senator's speech after the landing of Columbus appears ludicrous if compared with the 1969 Alcatraz Proclamation. The senator says, "[w]e've been victorious over them [Native Americans] on the battlefield, now they must settle on the reservations we [the white settlers] have generously set aside for them" (Geiogamah 1980, 52-53), whereas the Alcatraz Proclamation reads:

We wish to be fair and honorable with the Caucasian inhabitants of this land, who as a majority wrongfully claim it as their, and hereby pledge that we shall give to the majority inhabitants of this country a portion of the land for their own, to be held in trust by the American Indian people-for as long as the sun shall rise and the rivers go down to the sea! (Geiogamah 1980, 55)

Throughout the play, Geiogamah relies on joking and mockery, which adds to the effectiveness of the basic seriousness of the content. Although Geiogamah claims in Kenneth Lincoln's MELUS interview that he deployed humour because "it removes the power from insults" (71), this strategy often results as sharp and biting. While the object of the humour varies from scene to scene, its function does not. The scintillating satirical strain, which runs throughout the play, allows the author to playfully expose the most traumatic events since European arrival and destabilize their power through mockery. Humour is then the prime vechicle in the play for elaborating dignity and hope for Native Americans. Although it provokes laughter, Foghorn is not only a source of inspiration for Indigenous viewers. It is also a serious drama about the United States' history of exile, dispossession, and indifference to sustained suffering, constituting a penetrating indictment of white American racism and genocidial horror. As the Assiniboine Sioux 
playwright William S. Robe says, "when people of color do it, playwriting (or any other art form) is political, because we empower ourselves, we take control of our past, present and future" (Pulitano 19).

Homi Bhabha, among others, has noted that stereotypes are a major strategy of colonial discourse, premised on the ambivalence of that which is always already known, and that which must be anxiously repeated. In his words, problematising stereotypes and acknowledging their status as an ambivalent mode of power and knowledge "demands a theoretical and political response that questions dogmatic and moralistic positions on the meaning of oppression and discrimination" (1997, 293). This is particularly important because of what critics call the "colonized mentality" or "internalized inferiority complex" (Pyke 551). George Tinker notes that Native Americans have internalized the illusion of white superiority just as deeply as white Americans have; as a result, they "participate in [their] own oppression" (118). Geiogamah seems to be aware of the dangers that stereotypes pose. In addressing some of the most painful social wounds, he therefore juxtaposes white and Native American cultures and philosophies to challenge not only the whites' false, myth-laden perception of Native Americans, but also the whites' images of themselves. In most cases, and following the oral tradition of storytelling by tribal elders, Geiogamah does that in a bawdy, boisterous way, piling on fact after fact about the moral vices or physical shortcomings of the latter and proceeding slowly to the climax. In scene 5, for example, Pocahontas tells her handmaidens about Captain Smith's impotence in a string of similarly exaggerated descriptions of the man as the one that follows:

He had such big legs. Such big, uh, arms, such big, uh, uh, chest. Such big, big head. Such big, big hands. Such big, big feet. Such big eyes. Such big mouth. Such big ears. Ooooooh, aaahaaa. (Geiogamah 1980, 63)

Delaying the unraveling of the story to gauge and/or intensify the interest of her audience, Pocahontas finally conludes her account, which culminates in the following disclosure:

"And the big captain was standing above me, looking down at me, breathing like a boy after a footrace, and I saw that his ...

He said to me, I love you, dear Pocahontas. I promise you it won't happen the next time, I promise, I promise, I promise" (Geiogamah 1980, 64).

Presenting whites as impotent (Captain Smith), corrupted (Watergate spy), incapable, wicked and villainous (Lone Ranger), narrow-minded and ignorant (First Lady), to mention a few portrayals of white Americans, Geiogamah undermines the illusion of white superiority as a rendered and unquestionable 
normative. Given that, according to Fanon, self-consciousness exists only by being acknowledged or recognized by the other $(1986,216)$, this misconception about the superiority of the white race has caused the lack of "reciprocal recognition" $(1986,225)$. Deprived of the acknowledgement of the other in historical relations between the colonizer and the colonized, crucial for winning "the certainty of oneself" (Ibid.), the colonized have become self-colonizing, that is, they take part in their own oppression. Using the stage to bring to light some episodes in American history of which white America would prefer to remain conveniently silent and to expose the contradictions between the perception and the social reality, Geiogamah creates a productive disordering of the established system of dominance and confronts racist stereotypes. In other words, as Weaver has noted using the phrase from the title of Dennis McPherson and Douglas Rabb's volume, Geiogamah helps Native readers to see and define themselves as "Indian from the inside" (5), rather than as defined by the dominant society. By subverting the pervasive negative stereotypes promoted by whites to justify their oppression and superiority, Geiogamah elaborates a sense of dignity and social hope for Native Americans.

\section{CONCLUSION}

Gerald Vizenor has noted that "the post-Indian warriors," as he calls Native American authors, "encounter their enemies with the same courage in literature as their ancestors once evinced on horses, and they create their stories with a new sense of survival" $(1994,4)$. Indeed, by documenting the violence of colonial imposition and scrutinizing the means by which Europe imposed and maintained its dominant discourse, Geiogamah performs an important role in "the fantastic and terrible story of survival" of those "who were never meant to survive," as Joy Harjo writes in one of her poems. Engaged in the critique of the reproduction of whiteness and in the struggle for the assertion of Native Americans' authentic rather than an imposed cultural personality, Geiogamah continues to perform both personal and collective empowerment of his peoples, thus preparing the grounds for the society that, in Bhabha's words, "entertains differences without an assumed or imposed hierarchy" $(1994,4)$. Given the present social and political situation in the world, particularly in the 'new' Europe, characterized by a critical lack of productive cultural interaction, Geiogamah's effort to question the foundations of white supremacy in the United States can be read from a much wider perspective. 


\section{WORKS CITED}

Ashcroft, Bill, Gareth Griffiths and Helen Tiffin. The Empire Writes Back: Theory and Practice in Postcolonial Literatures. 2nd ed. London: Routledge, 2002.

Bhabha, Homi. The Location of Culture. London, New York: Routledge, 1994.

Bhabha, Homi. "The Other Question: The Stereotype and Colonial Discourse." Twentieth Century Literary Theory: A Reader. Ed. K. M. Newton. Palgrave, London: Macmillan Publishers Limited, 1997.293-301.

Brisbane, Katharine. "Introduction." Australia Plays: New Australian Drama. Ed. Katherine Brisbane. London: Nick Hern Books, 1980. xv.

Carter, David and Kay Ferres. "The Public Life of Literature." Culture in Australia: Policies, Publics and Programs. Eds. Tony Bennett and David Carter. Cambridge: Cambridge University Press, 2003. 140-160.

Crow, Brian and Chris Banfield. An Introduction to Postcolonial Theatre. Cambridge: Cambridge University Press, 1996.

Darby, Jaye T. "People with Strong Hearts: Staging Communitism in Hanay Geiogamah's Plays Body Indian and 49." Native American Performance and Representation. Ed. Stephen E. Wilmer. Tucson: University of Arizona Press, 2009. 155-170.

Davis, John A. The Negro Writer and His Roots. New York: American Society of African Culture, 1960.

Deloria, Vine, Jr. "Indian Humour." Native American Literature: An Anthology. Ed. Lawana Trout. Chicago: NTC Contemporary Publishing Group, 1999. 634-662.

Duran, Eduardo and Bonnie Duran. Native American Postcolonial Psychology. Albany, NY: State University of New York Press, 1995.

Fanon, Frantz. Black Skin, White Masks. London: Pluto Press, 1986.

Geiogamah, Hanay. New Native American Drama: Three Plays. Norman: University of Oklahoma Press, 1980.

Geiogamah, Hanay. "The New American Indian Theater: An Introduction." American Indian Theater in Performance: A Reader. Eds. Hanay Geiogamah and Jaye T. Darby. Los Angeles: UCLA American Indian Studies Center, 2000.

Goldberg, David T. "Introduction: Multicultural Conditions." Multiculturalism: A Critical Reader. Ed. David T. Goldberg. Oxford, Cambridge: Blackwell, 1994. $1-41$.

Gonzales, Madelena and Rene Agostini. Asthetics and Ideology in Contemporary Literature and Drama. Newcastle upon Tyne: Cambridge Scholars Publishing, 2015.

Hage, Ghassan. Against Paranoid Nationalism: Searching for Hope in a Shrinking Society. Annandale: Pluto Press, 2003.

Harjo, Joy. She Had some Horses. Thunder's Mouth Press, 1983. 
Haugo, Ann. "American Indian Theatre." The Cambridge Companion to Native American Literature. Eds. Joy Porter and Kenneth M. Roemer. New York: Cambridge University Press, 2005. 189-204.

Huntsman, Jeffrey. "Introduction." New Native American Drama: Three Plays. By Hanay Geiogamah. Norman: University of Oklahoma Press, 1980. ix-xxiv.

Krupat, Arnold. "Postcolonialism, Ideology, and Native American Literature." Postcolonial Theory and the United States. Eds. Amrithit Singh and Peter Smith. Jackson: University Press of Mississippi, 2000. 73-94.

Lincoln, Kenneth. “MELUS Interview: Hanay Geiogamah.” MELUS 16 (1989): 69-81.

Lipsitz, George. The Possessive Investment in Whiteness: How White People Profit from Identity Politics. Philadelphia: Temple University Press, 2006.

Marken, Jack W. "New Native American Drama: Three Plays by Hanay Geiogamah." American Indian Quarterly 5.4 (1979): 375-379.

McPherson, Dennis and J. Douglas Rabb. Indian from the Inside: A Study of Ethno-Metaphisics. Thunder Bay: Lakehead University, Centre for Northern Studies, 1993.

Mignolo, Walter. “On Subalterns and Other Agencies.” Postcolonial Studies 8.4 (2005): 381-407.

Mills, Charles. "Race and the Social Contract Tradition." Social Identities 6.4 (2000): 441-462.

Mills, Charles. "Breaking the Racial Contract." Dissent 62.4 (2015): 43-45.

Mojica, Monique. "Theatrical Diversity on Turtle Island: A Tool Towards the Healing." Canadian Theatre Review 68 (1991): 1-3.

Ngugi, wa Thiong'o. "The Language of African Literature." The Postcolonial Studies Reader. Eds. Bill Ashcroft, Gareth Griffiths and Helen Tiffin. London, New York: Routledge, 2003. 285-290.

Pearson, Julie. "Acts of Transfer: The 1975 and 1975 Productions of Raven and Body Indian." Querying Difference in Theatre History. Eds. Scott Magelssen and Ann Haugo. Cambridge Scholars Publishing, 2007. 114-125.

Pulitano, Elvira. "Telling Stories Through the Stage: A Conversation with William Yellow Robe." Studies in American Indian Literatures 10.1 (Spring 1998): 19-44. Pyke, K. D. "What is internalized racial oppression and why don't we study it? Acknowledging racism's hidden injuries.” Sociological Perspectives 53.4 (2010): 551-572.

Ruffo, Armand Garnet. "Why Native Literature?” American Indian Quarterly 21.4 (1997): 663-673.

Said, Edward W. Culture and Imperialism. New York: Vintage, 1994.

Stoudt, Charlotte, ed. Stages of Transformation. New York: Theatre Communcations Group, 2005. 
Suleri, Sara. The Rhetoric of English India.” The Postcolonial Studies Reader. Eds. Bill Ashcroft, Gareth Griffiths and Helen Tiffin. London, New York: Routledge, 2003. 111-113.

Taylor, Diana. The Archive and the Repertoire. Durham: Duke University Press, 2003. Tiffin, Helen. "Postcolonial Literatures and Counter Discourse." The Postcolonial Studies Reader. Eds. Bill Ashcroft, Gareth Griffiths and Helen Tiffin. London, New York: Routledge, 2003. 95-98.

Tinker, Geoge. Missionary Conquest. Minneapolis: Fortress Press, 1993.

Van Der Horn-Gibson, Jodi. "Constructing the Fruited Plain: The Red, the White and the Imbued." Querying Difference in Theatre History. Eds. Scott Magelssen and Ann Haugo. Cambridge Scholars Publishing, 2007. 126-132.

Weaver, Jace. That the People Might Live: Native American Literatures and Native American Community. New York: Oxford University Press, 1997.

Wilson, Norma. "New Native American Drama: Three Plays by Hanay Geiogamah." Studies in American Indian Literature 7.4 (1983): 84-87.

Vizenor, Gerald. Manifest Manners: Postindian Warriors of Survivance. Honover, N. H.: Wesleyan University Press, 1994.

Danica Čeř̌e University of Ljubljana danica.cerce@ff.uni-lj.si

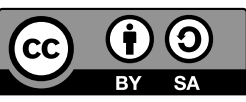

\section{Destabilizacija dominantnega diskurza v dramskih delih Body Indian in Foghorn Hanayja Geiogamaha}

Prispevek obravnava drami Body Indian in Foghorn sodobnega ameriškega staroselskega avtorja Hanaya Geiogamaha. Z izhodiščem v kritiški misli o pomembni družbeni vlogi književnih besedil in opirajoč se na postkolonialno kritiko, raziskuje, kako dramatik posega $\mathrm{v}$ domneve o beli rasi kot trajno priviligirani kategoriji in neukinljivi dominanci.

Ključne besede: ameriška staroselska dramatika, Hanay Geiogamah, Body Indian, Foghorn, destabilizacija evropocentrizma 